\title{
METAPHOR EXPRESSION IN FALL FOR YOU SONG LYRICS
}

\author{
Faidah Yusuf ${ }^{1}$, Andi Reski Amelia ${ }^{2}$ \\ State Islamic University of Alauddin Makassar \\ Ifaidahyusuf8@gmail.com \\ ${ }^{2}$ areskiamelia@gmail.com
}

\begin{abstract}
The purpose of this article is to analyze the type of metaphor and analyze the meaning in the lyrics of the song "Fall for You" the method uses a qualitative approach because the data used in the form of song lyrics. Document analysis is applied to find the connotation meaning contained in the song lyrics, the messages contained in the song, as well as the contribution of the connotations to the messages in the song. The writers collected data by downloading songs along with lyrics, reading song lyrics, and creating phrases that contain metaphorical meanings. Then the writers analyzed the data by identifying the meaning, find the intent contained in the song, and connect with the types of metapor. The results of the discussion data show that there are. There are seven types of meaning in the data are: conceptual, connotative, social, affective, reflective, collocative and thematic meaning. The song uses metaphor and other types of meaning to embellish the song and to convey the implicit message in the song. The messages contained in the song are mostly persuasive. metaphors found in song lyrics have an important role in creating certain feelings and conveying messages.
\end{abstract}

Keywords: Metaphor, Meaning, Song lyrics

\begin{abstract}
ABSTRAK
Tujuan dari artikel ini adalah untuk menganalisa jenis metafora dan menganalisa makna dalam lirik lagu "Fall for You". Metodenya menggunakan pendekatan kualitatif karena data yang digunakan dalam bentuk lirik lagu. Analisis dokumen diaplikasikan untuk menemukan makna konotasi yang terkandung dalam lirik lagu, pesan yang terkandung dalam lagu, serta kontribusi konotasi terhadap pesan dalam lagu tersebut. Peneliti mengumpulkan data dengan mendownload lagu beserta liriknya, membaca lirik lagu, dan membuat ungkapan yang mengandung makna metafora. Kemudian para peneliti menganalisis data dengan mengidentifikasi maknanya, menemukan maksud yang terkandung dalam lagu, dan terhubung dengan jenis-jenis metapor. Hasil dari data diskusi menunjukkan bahwa ada. Ada tujuh jenis makna dalam data tersebut yaitu: makna konseptual, konotatif, sosial, afektif, reflektif, kolektif dan tematik. Lagu tersebut menggunakan metafora dan jenis makna lainnya untuk memperindah lagu dan menyampaikan pesan implisit dalam lagu tersebut. Pesan yang terkandung dalam lagu sebagian besar bersifat persuasif. Metafora yang ditemukan dalam lirik lagu memiliki peran penting dalam menciptakan perasaan dan menyampaikan pesan.
\end{abstract}

Kata kunci: Metafora, Makna, lirik lagu 


\section{A. INTRODUCTION}

Language is a communication tools that has several functions in daily life. One of the functions of the language is to express thought. It means language is used to communicate wills or feelings with others. The language serves an expressive or emotive function.

The expressive function can be found, for instance, in song lyrics. In the song lyrics, the composers can freely express their feelings with their hearers. It is reflected from the use of metaphorical language (Macmillan, 1995). Metafora also a characteristic of language just more literature. That language using in daily life (Susilowati, 200).

Metaphor is characteristic of language. We habit using in daily life. Metaphor is a spesific abstraction to discuss something, give understanding to the world. Grammatical metaphor is one of the most significant components of systematic functional grammar, which plays a central role in transiting clauses to discourses.

Communication is an important part in our daily life. Also, communication is a process someone to related with other people. Communication has several kind, including expression with a song. Every song has a lyrics. In song, a lyrics are written in simple form. Thus, listeners easy to understand. In addition, the lyrics represent the writer's mind, then listeners sometimes prefer a song by the lyrics. So, the data which were analyzed are methaporical meaning in song lyric.

This article is to analyze about the type of metaphor and analyze the meaning in the lyrics of the song "Fall for You" by Secondhand Serenade. Then need to analyze the song by identifying the meaning, find the intent contained in the song, and connect with the types of metapor. There are seven types of meaning in the data are: conceptual, connotative, social, affective, reflective, collocative and thematic meaning. The song uses metaphor and other types of meaning to embellish the song and to convey the implicit message in the song. The messages contained in the song are mostly persuasive. metaphors in song lyrics have an important role in creating certain feelings and conveying messages.

\section{B. PERTINENT IDEAS}

Language is a fundamental device used by people to communicate. A sentence or an utterance in which people use to express their feelings and thoughts is generally containing either literal meaning or non-literal meaning. One kind of nonliteral meaning is connotative meaning which is subjective and not perceived the same way by the speakers of a language (Prayitna, 2015)

A metaphorical expression is one in which the line is indirect. To put it in another way, the concept of "congruent" means the pattern of relationships between the semantics and the grammar in which the two strata initially coevolved. Here the "two strata" is not plainly clarified. Yet the proposition that language is a multi-level system is the most critical clue to elaborate the term "congruent". In the light of this idea, linguistic system is composed of three strata: 
semantic (the meaning), lexicogrammatical (the wording), and phonology (the sound) (Halliday, 1994 dan 1996).

Metaphors originates in the ancient Greece more than two thousand years ago. Ever since the time of Aristotle, academia from various fields has conducted researches on this subject from different perspectives. Fruitful results have been reaped through the efforts of philosophers, cognitive psychologists, and linguists ( Tang, 2004).

According to Lakoff and Johnson (1980) in Widiassrini (2017). metaphorical expressions are used in daily language or conversation, whether it is written or spoken. Metaphor is very important in daily activities. It can be found in song lyrics, poetry, or in any kind of literary works. Therefore, it is very interesting to understand about the meaning. Metaphor refers to another concept or meaning semantically. Basically, in daily spoken language, there are two different concepts which are used in order to produce a metaphorical expression.

Leech (1976) in Chaer (1995:59) divides meaning into seven types:

1. Conceptual meaning

2. Connotative meaning

3. Social meaning

4. Affective meaning

5. Reflective meaning

6. Collocative meaning

7. Thematic meaning

Leech (1979) has classified figurative meaning into eight types. They are: personification, simile, metaphor, hyperbole, irony, litotes, metonymy and oxymoron. This research is focused on the use of metaphor. Metaphor is a kind of figurative meaning which is an implicit comparison in which two unlike objects are compared by identifying or substituting one with other. it is stated that a figure of speech which makes a comparison between two seemingly unlike things is called Metaphor.

Odgen dan Richards (1972: 213) said that metaphor, in the most general sense, is the use of one reference to a group of things betwen which a given relation holds for the purpose of facilitating the discrimination of an analogous relation in another group.

Based on definition, can conclude that metaphor has three domain:

1. As comparing (vehicle or source domin) is a concept, object that describe, talk, and symbol.

2. The word figurative itself

3. The equation between comparator (ground or sense) is the relation of the equation between the target domain and vehicle or source domain (Richard, 1965). 
It can be stated that a metaphor is figure of speech in which a word or phrase is taken out of its usual setting and placed with another word to suggest a likeness.

It is made more vivid by transferring to it the name or attributes of some other objects (Fitriani, 2017).

\section{Conceptual meaning}

Conceptual metaphors theory (CMT), pioneered by Lakoff and Johnson (1980), is driven by the notion that metaphors are pervasive in everyday life. In this theory, how people think and act is metaphorical in nature. Thus, the metaphor can be found not only in language but also in though and action. In other words, language is only one of the realizations of conceptual metaphor (Saraswhati, 2017).

Conceptual meaning refers to the logical sense of the utteranceand is recognizable as a basic component of a grammatically described as the cognitive or the denovative meaning (Yusuf, 2017).

What Leech calls as conceptual meaning was the same as what other scholars call'denotative', or 'designative', or 'cognitive', or 'descriptive' meaning. This meaning was assumed to be the central factor in linguistics communication. It was integral to the essential functioning of a language while other types of meaning are not. Leech considers conceptual meaning as primary because it was comparable in organization and structure to the syntactic and phonological levels of language. The two structural principles that seem to be basis of all linguistics patterning namely the principle of contractiveness and the principle of structure are also the basis of conceptual meaning (Saraswhati, 2017).

\section{Connotative meaning}

Tarigan (1986) assert that connotative meaning is what people think about two words and find whether it is possible or impossible for the word to have two different meanings from its denotative meaning. Based on it, the meaning depends on personal interpretation. Sometimes, people have the same or different thought.

Leech's (1990) connotative meaning was concerned with the real world experiences one associates with the linguistics expression one uses or hears. Connotative meaning was peripheral when compared with the conceptual meaning. It was also relatively unstable as it varies according to culture, historical periods and experience of the individual.

Connotative meaning was indeterminate and open ended. This was because this depends upon the knowledge and beliefs of the speakers and may belong to any characteristics of the referent, real or imaginary as identifies by the speaker. But conceptual meaning consist of a closed set of features which are finite in number (Saraswhati, 2017).

\section{Social Meaning}

The meaning is concerned with two aspects of communication which are derived from the situation or environment in which an utterance or sentence was produced in a language. Of these two, social meaning was that 
information which a piece of language (i.e. a pronunciation variation, a word, phrase, sentence, etc.,) conveys about the social circumstance of its use. Social meaning was understood through the recognition of different dimension and level of style within the same language. Aspects of language variation like social or regional dialect variation, style variation like formal, informal, colloquial, slang etc., in a social situation a functional meaning of a sentence may differ from its conceptual meaning due to its illocutionary force.

\section{Affective meaning}

Affective meaning was the aspects of meaning which "reflects personal feelings of the speaker, includes the attitude of the listener or his attitude to something the listener was talking about. But leech's includes as in the case of social meaning, not only difference in the use of words or lexemes but also factors of the realizations of conceptual metaphor (Neilil, 2017).

\section{Reflected}

This type of meaning are due to relation between words or interconnection on the lexical level of language. Of the two, reflected meaning was the meaning which arises in cases when a word has multiple conceptual meaning or polysemous, when one sense of a word form part of our response (or reaction) to another sense. Collocative meaning consists of the association a word acquires on account of the meaning of words which tend to occur in its environment (Neilil, 2017).

\section{Collocative meaning}

Collocations have their place in lingusitic because it is indeed a type of meaning that offers associations of a word with other menaings of the word in certain environment. Collocative and semantics live in symbiosis each other, each word in very spesific context. (Michaud, 2017)

\section{Thematic meaning}

Lysons (1995:154) dalam Yusuf, 2017 states that one part of the meaning of sentences as sentences are commonly defined. That is definitely not part of their propotional content is thematic meaning. For example, the following sentences, which differ in thematic meaning, all have the same truth conditions, and therefore the same propositional content:

a. I have not read this book

b. This book i have not read

c. It is this book (that) i have not read

d. This book has not been read by me

The meaning arising out of the way in which the writer or speaker organizes his message is called thematic meaning.

The example are:

a. Tomorrow i plan to have an outing 
b. I plan to have an outing tomorrow

Furthermore, it can be concluded from the discussion that associating (in metaphors) is part of human cognitive system since basically humans like relating something with other things (Neilil, 2013).

\section{RESEARCH METHOD}

The data of this study were collected from the lyrics "Fall For You" by Secondhand Serenade downloaded from Internet. The data of this study were collected using the note taking technique. The steps are, First of all the choosen songs were downloaded. The lyrics were downloaded out of the official website of Download Lagu.

The following approaches were listening the songs and reading the song lyrics of the choosen songs attentively with the major focus on identifying the metaphorical expressions within each song. The next step was note taking the metaphorical expressions found in the songs. The data were analyzed using the qualitative method. the steps of analyzing data were identified and classified based on the types of metaphor proposed by Lakoff and Johnson (1980); finally, the data were analyzed using the theory purposed by Leech (1974) to get the meaning.

\section{DISCUSSION}

Irvine and Kirkpatrick (1972) make more concrete arguments for music as social movement. They see four reasons for viewing music in this way. First, music uses a symbol system in order to convey a message. Second, this message, delivered through music, can affect the judgments of listeners, thus having a persuasive impact. Third, musical form changes the rhetorical message from its normal discursive state into a specific state which still serves to deliver a message.

Finally, because music has been considered in terms of entertainment, it is insulated from moral and/or cultural restraints imposed on verbal discourse.

The listeners of the songs not only enjoy the tones of the music, but also the lyrics. The lyrics represent the writer's mind and help the listeners to understand what is in the writer's mind. In addition, the listeners sometimes prefer a song for the lyrics. Therefore, the lyrics can alsotake a role in determining whether a song will be favored or not (Ekaningrum, 2015).

This document using "Fall For You" lyrics: by Secondhand Serenade:

The best thing 'bout tonight's that we're not fighting

Hal terbaik yang terjadi malam ini adalah bahwa kita tak bertengkar

Could it be that we have been this way before?

Pernahkah kita seperti ini sebelumnya?

I know you don't think that I am trying

Aku tahu kau kira aku tak mencoba

I know you're wearing thin down to the core

Aku tahu kesabaranmu telah habis 
But hold your breath

Namun tahanlah nafasmu

Because tonight will be the night

Karna malam ini adalah saatnya

That I will fall for you over again

Aku akan jatuh cinta padamu lagi

Don't make me change my mind

Jangan sampai aku berubah pikiran

Or I won't live to see another day

Atau lebih baik aku mati

I swear it's true

Aku bersumpah

Because a girl like you is impossible to find

Karena tak mungkin kutemukan gadis sepertimu

You're impossible to find

Tak mungkin kutemukan (gadis seperti) dirimu

This is not what I intended

Ini bukan yang kuharapkan

I always swore to you I'd never fall apart

Aku selalu bersumpah padamu aku takkan pernah hilang kendali

You always thought that I was stronger

Kau selalu mengira aku lebih tangguh

I may have failed, but I have loved you from the start

Mungkin aku memang gagal, tapi aku mencintaimu sedari semula

But hold your breath

Namun tahanlah nafasmu

Because tonight will be the night

Karna malam ini adalah saatnya

That I will fall for you over again

Aku akan jatuh cinta padamu lagi

Don't make me change my mind

Jangan sampai aku berubah pikiran

\section{Conceptual Meaning}

To explain about conceptual or denotative meaning is logical meaning and propositional meaning which corresponds to the primary dictionary definition. For knowing the meaning we directly confirm to see the dictionary.

You're impossible to find

It could be said that, as the meaning explained for the words "find", the line then can be simply mean that the devoted person in the song "You" may experience got something that never before. The meaning can be understood conceptually 
based on the definition found in the dictionary. To conclude, this line can be categorized as having conceptual or denotative meaning.

\section{Connotative Meaning}

Connotative meaning is something that goes beyond referent of a word and hints at its attributes in the real world. The meaning of connotative meaning can only be taken imaginatively, and can fix by asking the other people who knows about the problem.

\section{Because Talk is cheap}

For explaining the meaning, further perception of either the songwriter or the listener or reader needs to be taken into account. "Talk" means speak in order to give information or express ideas or feelings. Connotation of "cheap" means an item for sale or we can said low in price. Itself leads the line to be having one kind of meaning in Leech's theory, that is, connotative meaning. Leech (1974) mentions that connotative meaning is a kind of meaning that goes beyond referent of a word and hint at its attributes in the real world.

\section{Social Meaning}

Social meaning refers to the use of language to establish and regulate social relations and to maintain social roles. This type of language use is alternatively described as social or phatic communication. Socail meaning is hence communicated through ritualistic use of language as found in greetings, apologies, blessing or condolences (Yusuf, 2017).

\section{Cuz a girl like you impossible to find}

Social meaning is the meaning that expression conveys about the coontext of its use. From the lyrics above. The word "Cuz" is colloquial that have formal form which is because.

\section{Affective Meaning}

In manner comparable to social meaning, affective meaning is only indirectly related to the conceptual representation. Affective meaning is more directly a reflection of the speaker's personal attitude or feelings towards the listener or the target of the utterance. Affective meaning is largely a prasitic category in the sense that to express our emotions we rely upon the meditation of other categories of meaning: conceptual, connotative, or stylush (Yusuf, 2017).

\section{But I have loved you from the start}

The word "star" is categorized as having affective meaning. The reason is that affective meaning is one kind of meaning that is used to reflect the personal feeling of the speakers including his attitude to the listener or his attitude to the something he is talking about, based on Leech (1974). In this case, the songwriter expresses his feeling that is "loved" in the lyric "But I loved you from the start". 


\section{Collocative Meaning}

Collocative meaning is one kind of meaning that consists of association of a word acquired on account of the meaning of words, which usually occur in its environment

\section{Or I won't live to see another day}

In the line "Or I won't live to see another day" the word "live". It is defined by KBBI (Kamus Besar Bahasa Indonesia) that still there, moving, and work as well as known. The phrase "another day" is said to be having c ollocative meaning based on Leech's theory of meaning. The reason is that the word "another" is collocated with the word "day" and it is usual or habitual co-occurrence with these words. Another day in our daily life wa can call is tomorrow.

\section{Thematic Meaning}

Thematic meaning was that "what was communicated by the way in which a speaker or writer organize the message, in terms of ordering, focus, and emphasis". The thematic meaning can also be expressed by means of stress and intonation to highlight information in one part of a sentence (Saraswathi, 2017).

\section{You always thought that I was stronger}

Based on lyrics, we can know that various parts of the sentence also can be used as subject, object, or complement to show prominence. We can said again in different context, like

I was stronger, you always though

Was I stronger that you always though?

\section{E. CONCLUSIONS}

Based on data discussion can be concluded that metaphor expression found in song lyrics that has a title "Fall For You". There were terminologies in lyrics that have interrelation of semantic The expressions are categorized into types of metaphors as proposed by Lakoff and Johnson (1980).

Leech in Chaer (1995:59) divides meaning into seven types :1) conceptual meaning, 2) connotative meaning, 3) social meaning, 4) affective meaning, 5) reflective meaning, 6) collocative meaning, 7) thematic meaning. In this case, all metaphor expression found in "Fall For You" lyrics except reflective meaning. Reflective meaning is the meaning which arises in cases of multiple conceptual meanings, when one sense of a word forms part of our response to another sense. Metaphor expression found in a lyrics to make song good in listener and to convey messages. 


\section{BIBLIOGRAPHY}

Ahmad, Aswad. 2014. A study of Metaphor in Bob Marley Songs. Journal of English.

Ekaningrum, Prastiana. 2015. The Analysis Of Meanings And Forms In The A.T Mahmud Song Lyrics. Journal of Arts Research and Education. Vol. 15(1): 915

Fitriani, Aisyah. 2017.Semantic and Semiotic Analysis of "Rere Mana Rere" Song in the Culture of Mandailing. International Journal of Linguistics. Vol. 9.No.3

Halliday, M.A.K.1994, An Introduction to Functional Grammar. London: Edward Arnold.

Halliday, M.A.K.1996, An Introduction to Functional Grammar. London: Edward Arnold

http://www.ifeas.unimainz.de/Swafo/SF11Mwihaki. pdf

Irvine, J. R., \& Kirkpatrick, W. G.(1972). The musical form inrhetorical exchange:Theoretical Considerations. Communication Research, 12(3), 58, 273-284.

Lakoff, G., \& Johnson, M. 1980. Metaphor we live by. Chicago: University of Chicago Press.

Leech, Geoffrey. 1990. Semantics : the study of meaning. London: Penguin.

Leech, G.N. 1979. Semantics. Auxland: Pengin Books

Macmillan, L. 1995. Linguistic Semantics. Cambridge: Cambridge University Press.

Michaud, Matthew. 2017. On Collocative Meaning. Journal of semantics and EFL.

Neilil, Selvia. 2013. Conceptual Metaphors in Mylo Xyloto Album by Coldplay. Journal of passage, vol. 1(2): 125-135

Ogden, C.K and I.A. Richards. 1972. The Meaning of Meaning. London: Routledge and Kegan Paul LTD.

Prayitna, Nadia Aprilia. 2015. An Analysis on Connotative Meaning and Message in Linkin Park's Songs in A Thousand Suns Album. Journal of Thesis.

Richards, Ivor Armstrong. 1965. The Philosophy of Rhetoric, Oxford University Press, Newyork.

Saraswatathi, Nadar. 2017. Leech's seven types of meaning in semantics. International Journal of Multidisciplinary Research and Development. Vol. 4(3): 71-72.

Susilowati, et all. 2007. Metaphor in the Lyric of Macapat Song. Journal international seminar prassati.

Tang, Ziqian. 2004. A unique Access to Classical Chinese Cultural Gem-Song CI from the Perspective of Grammatical Metaphor. Cambridge Journal of China Studies:49. 
Tarigan, Guntur Henry. 1993. Pengajaran Semantik. Penerbit Angkasa Bandung

Widiassrini, kadek, et all. 2017. English Metaphor In "Just Take My Heart" And "Angel” Song Lyrics. Jurnal Humanis, Fakultas Ilmu Budaya Unud. Vol. 18 (1): 115-121. 